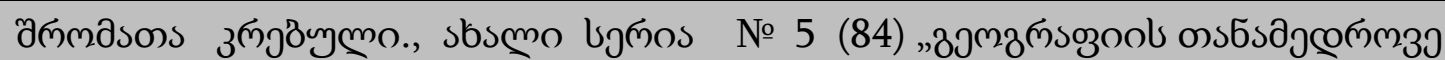

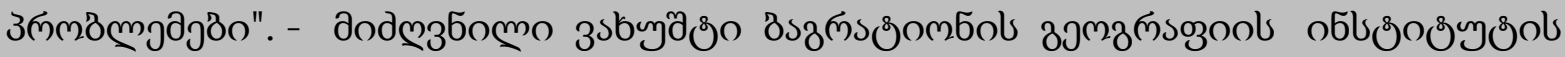

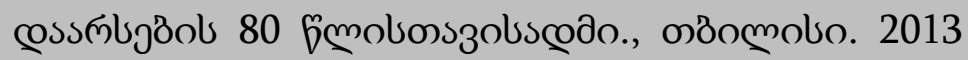

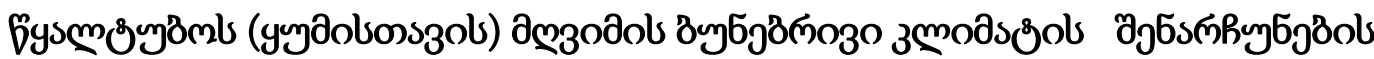

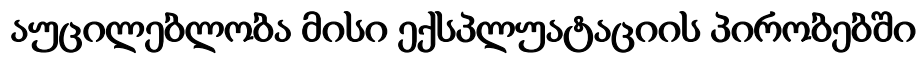

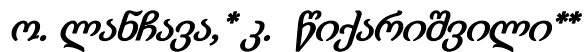

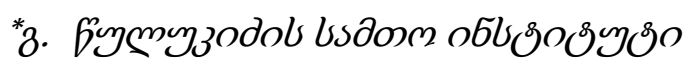

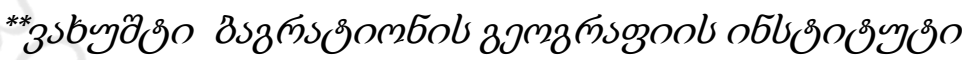

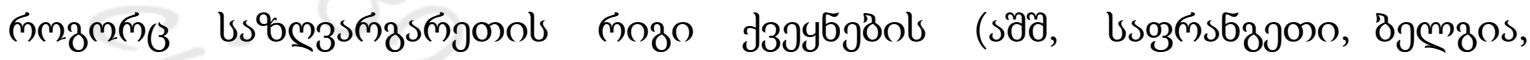

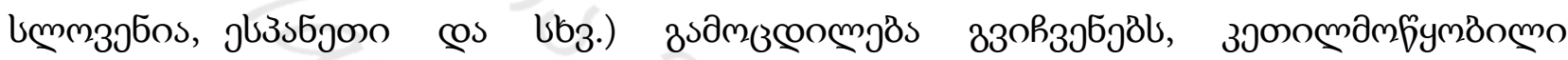

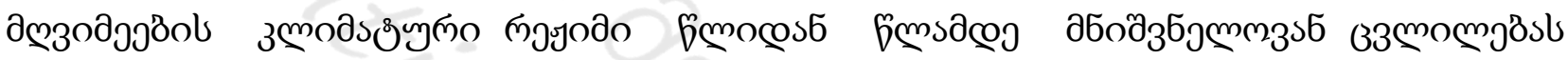

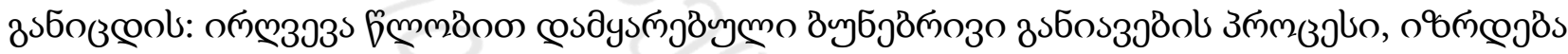

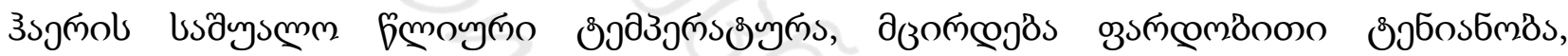

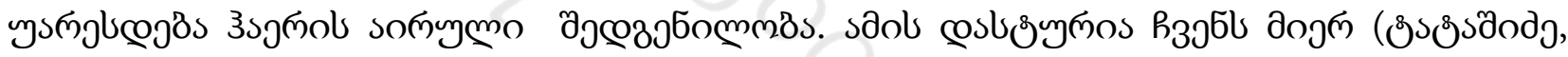

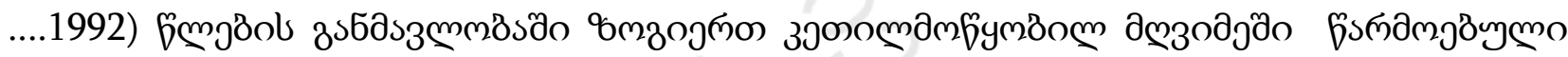

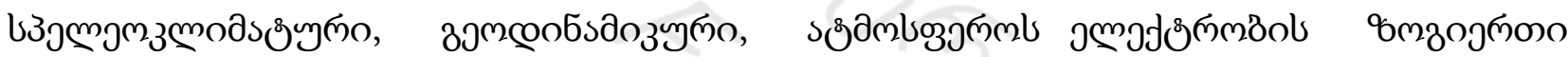

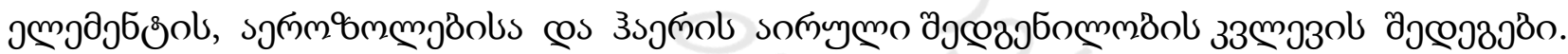

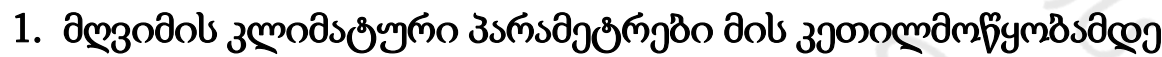

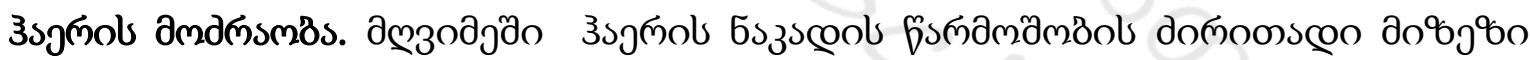

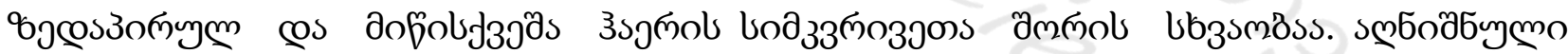

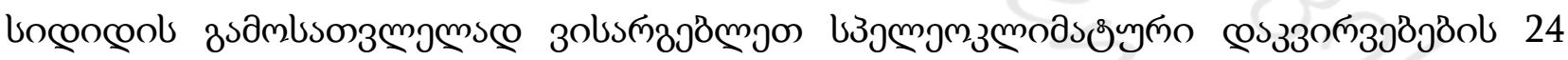

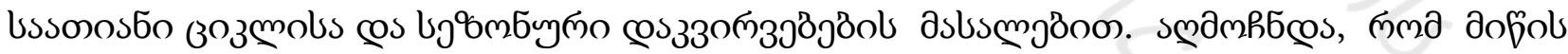

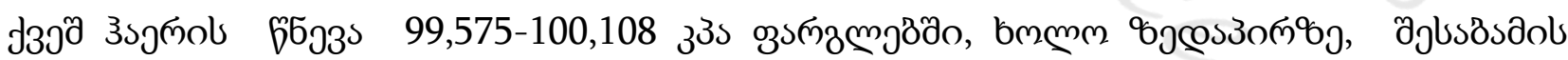

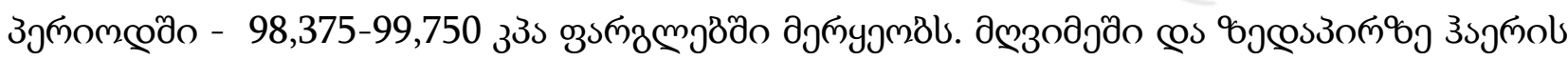

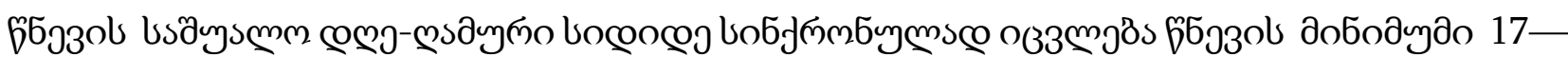

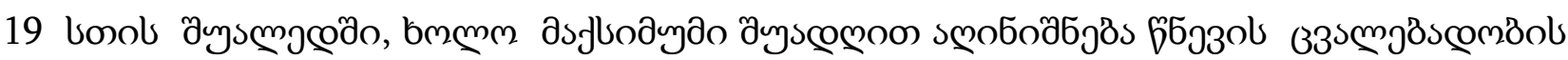

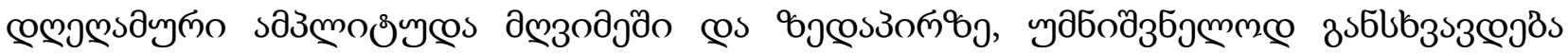

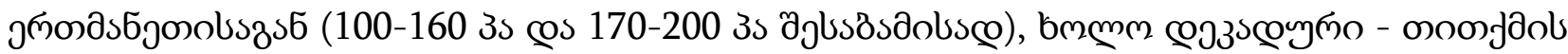

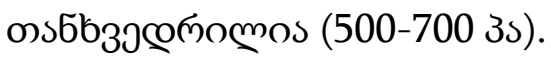

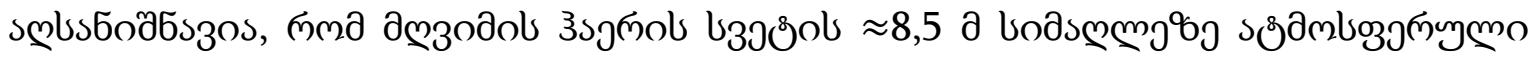

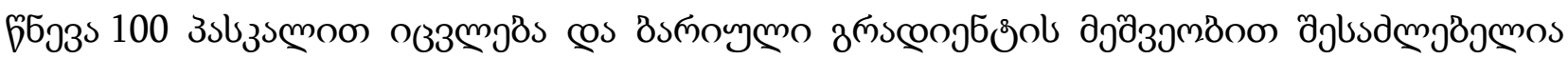

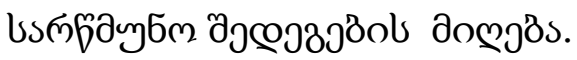




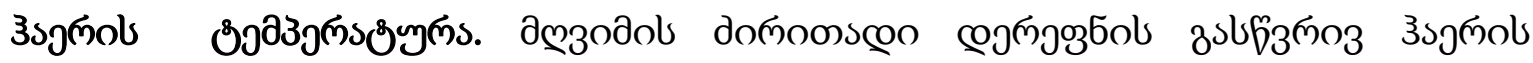

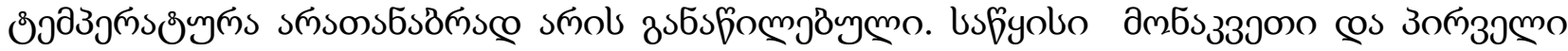

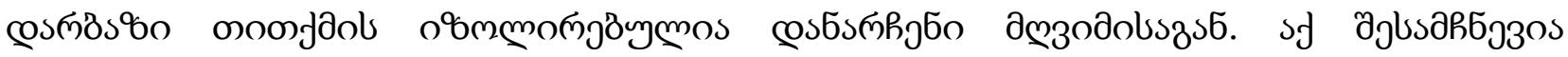

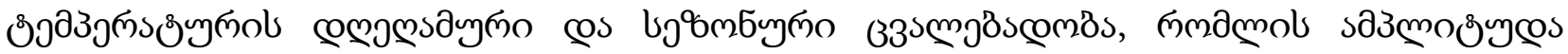

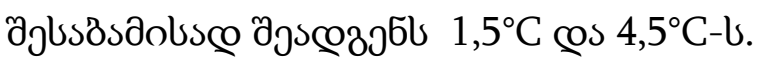

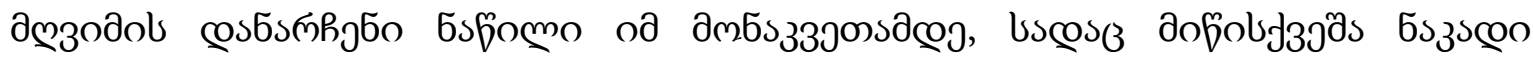

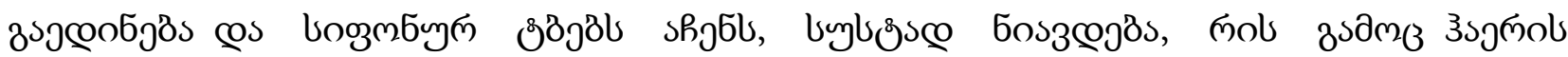

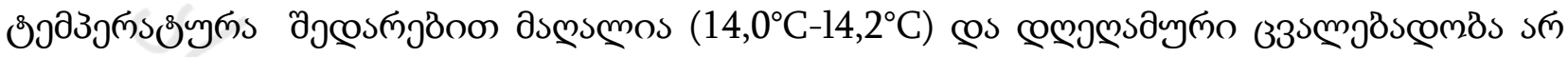

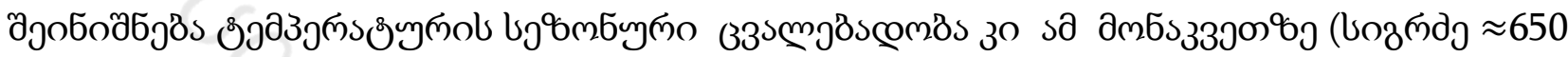

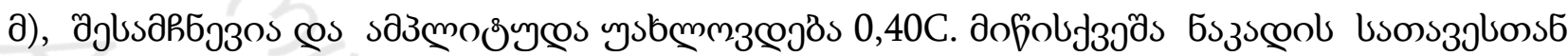

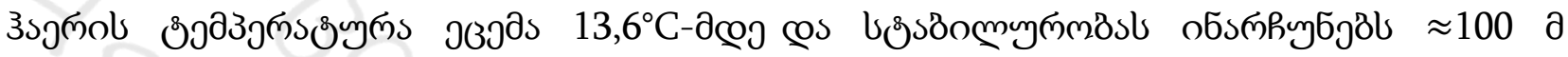

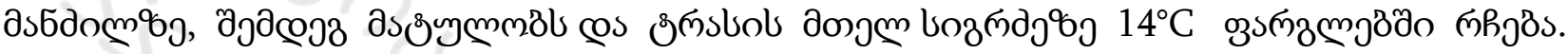

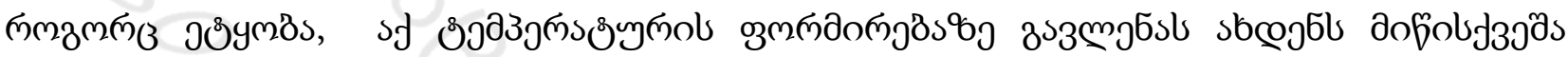

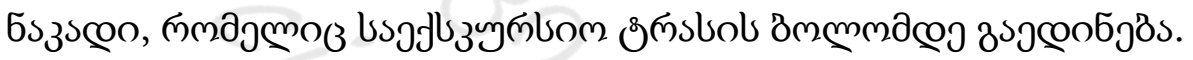

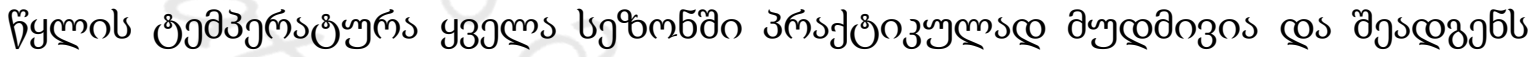

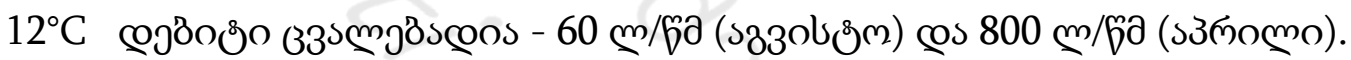

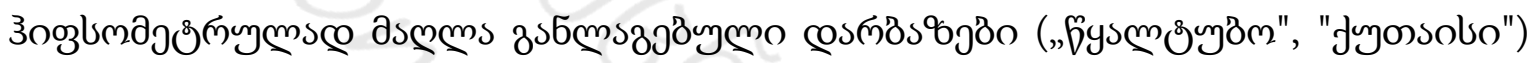

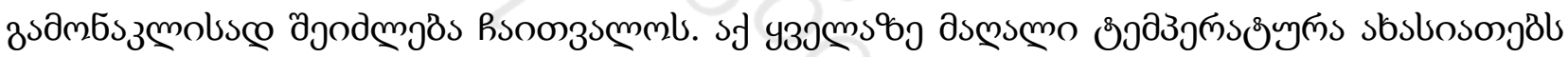

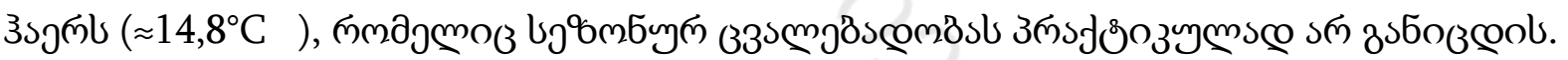

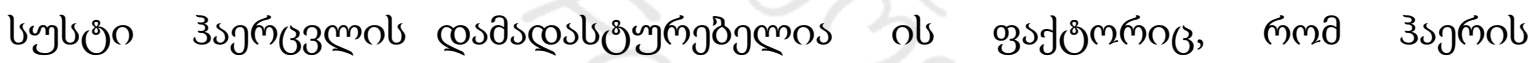

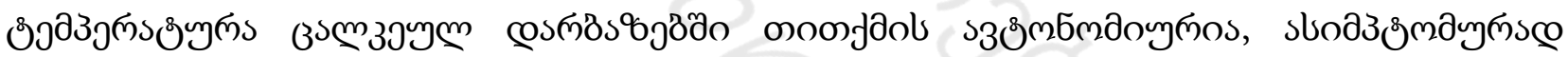

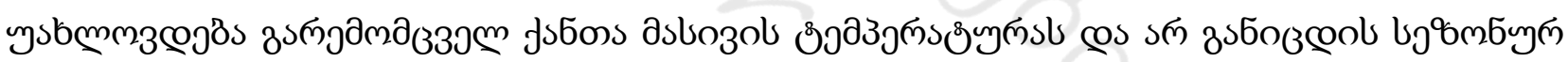

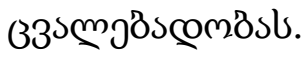

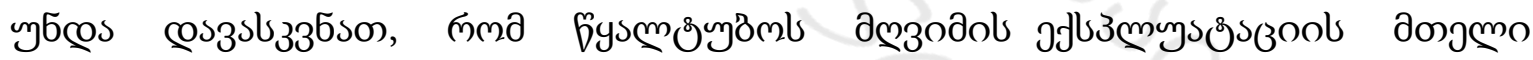

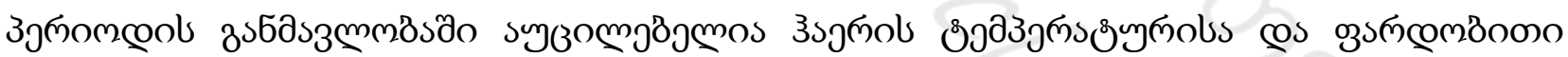

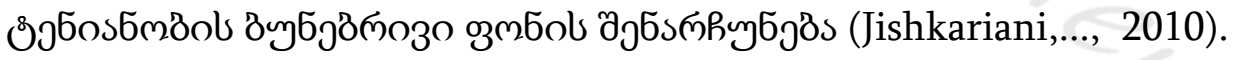

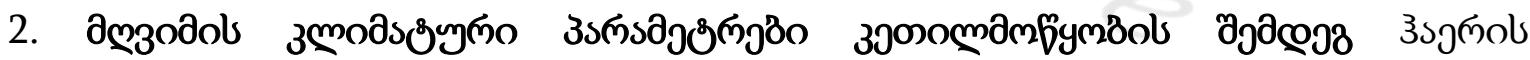

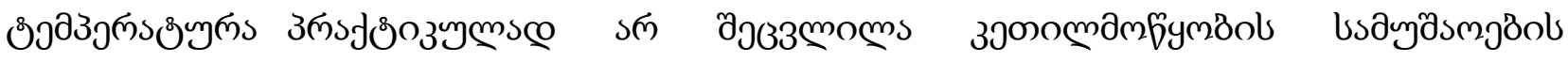

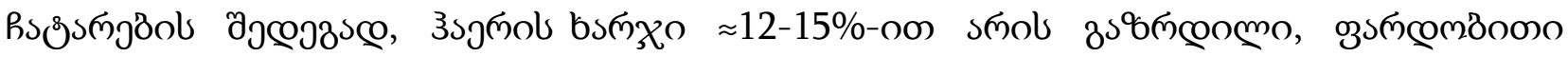

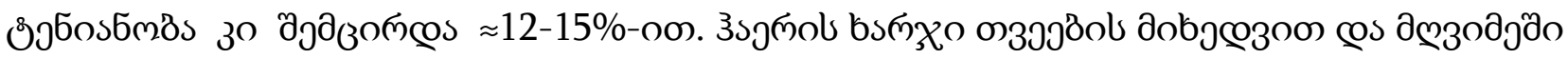

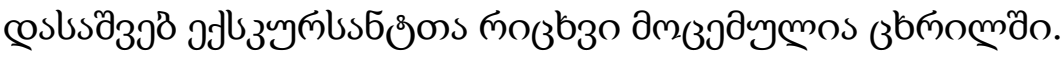




\begin{tabular}{|c|c|c|c|c|}
\hline $\mathrm{N}^{2}$ & $\omega_{30 \partial^{\partial o}}$ & 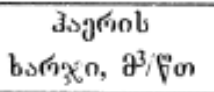 & 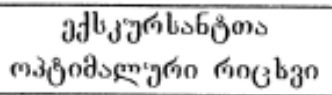 & 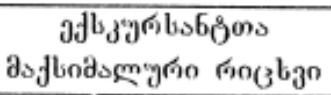 \\
\hline 1 & 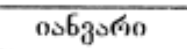 & 57,5 & 7068 & 10780 \\
\hline 2 & 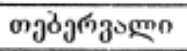 & 55,2 & 6216 & 9240 \\
\hline 3 & 2ஃศరిం & 46,0 & 5580 & 8556 \\
\hline 4 & ১3గngmo & 23,0 & 2700 & 4278 \\
\hline 5 & asobo & 39,1 & 4500 & 7020 \\
\hline 6 & o36olo & 49,5 & 5760 & 9000 \\
\hline 7 & ozenobo & 57,0 & 6882 & 10230 \\
\hline 8 & ా030lరిm & 58,3 & 7068 & 10788 \\
\hline 9 & เวฝฮిว & 48,3 & 5760 & 9000 \\
\hline 10 & мдช̊mдةgro & 25,3 & 2976 & 4650 \\
\hline 11 & 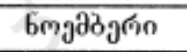 & 32,2 & 3780 & 5760 \\
\hline 12 & ฉองวว & 50,6 & 6138 & 9486 \\
\hline
\end{tabular}

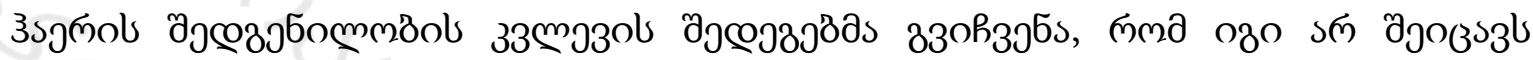

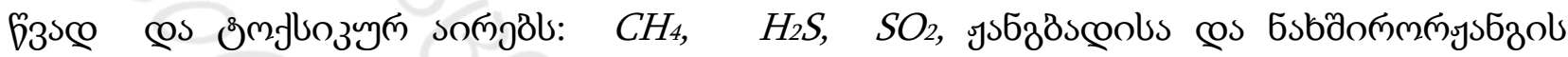

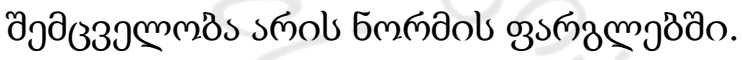

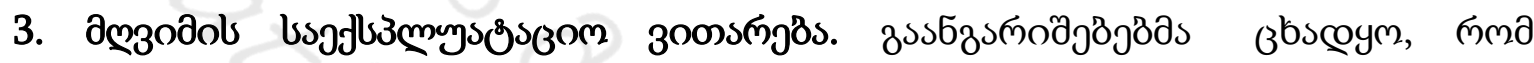

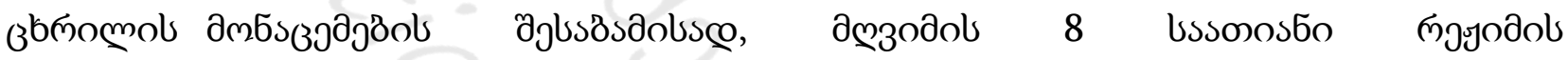

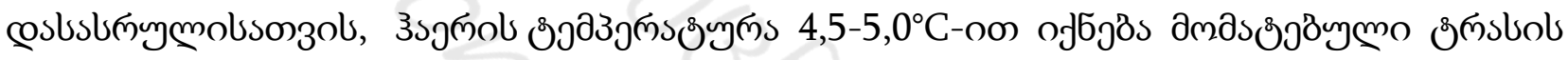

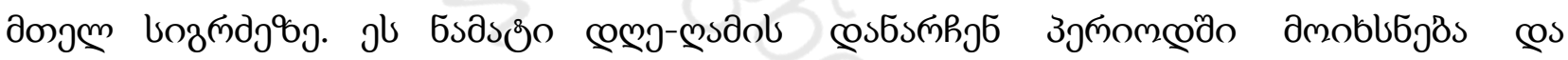

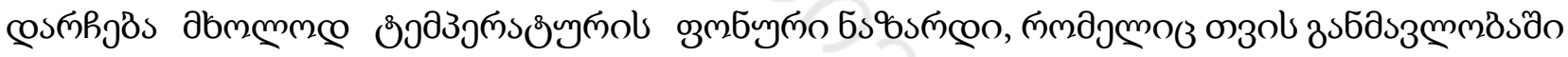

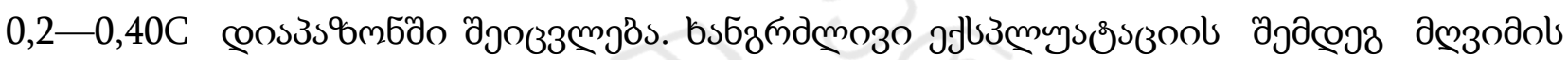

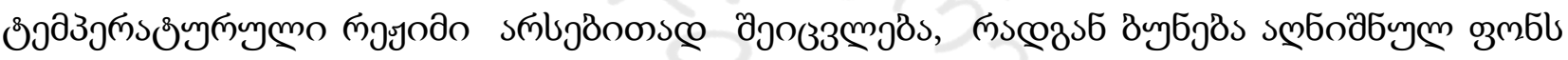

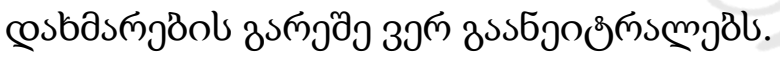

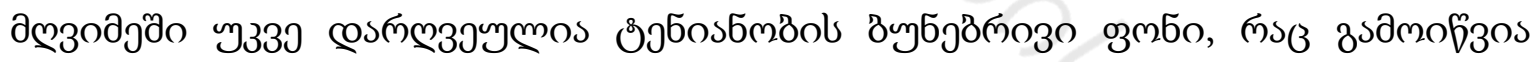

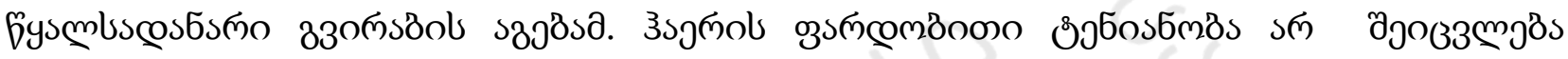

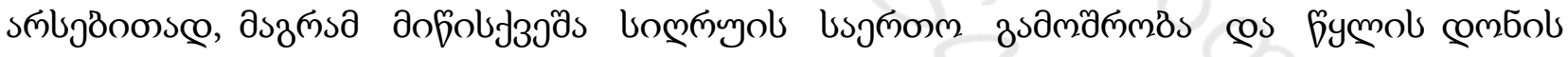

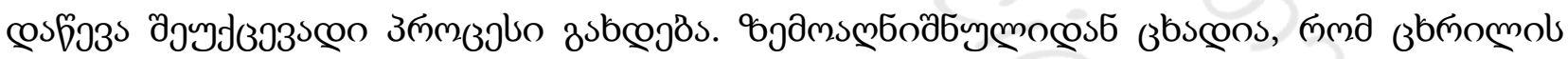

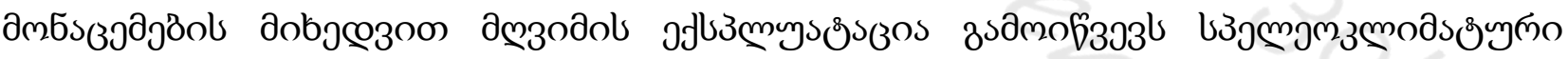

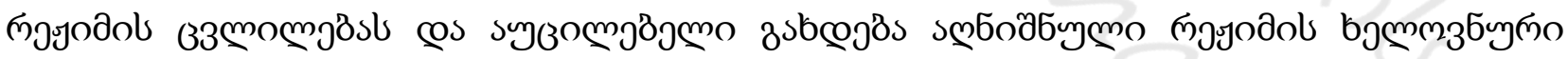

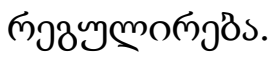

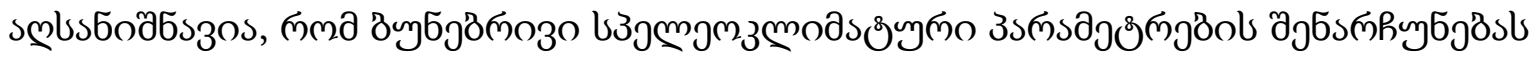

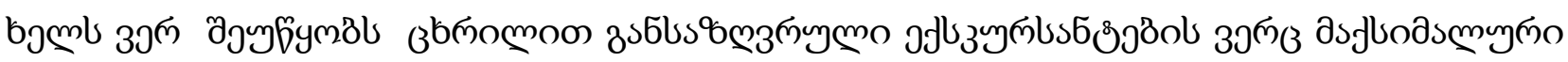

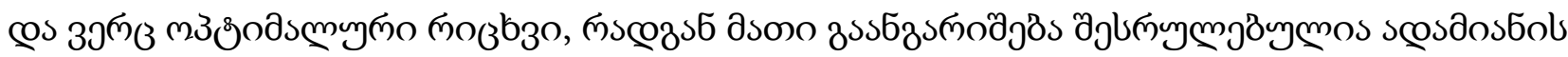

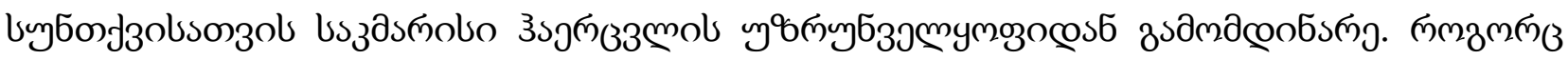

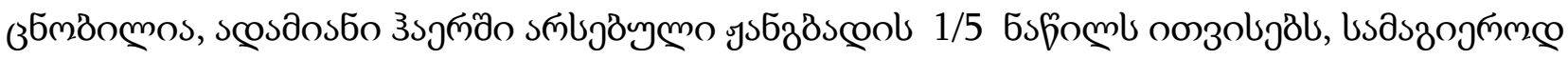

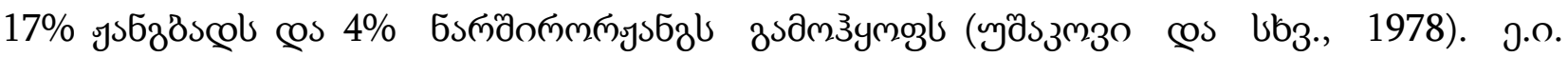

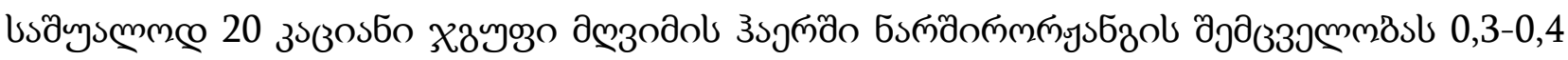

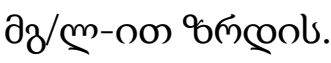




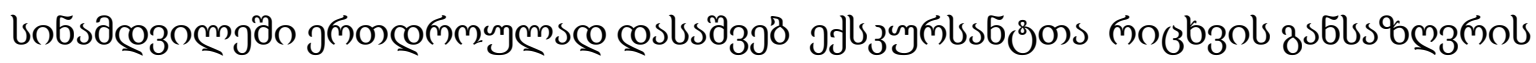

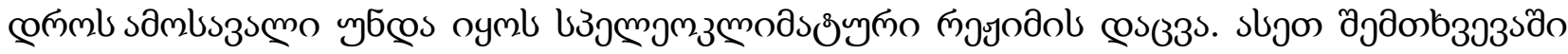

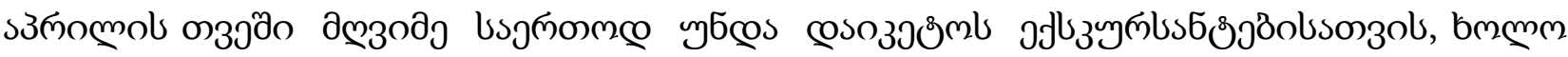

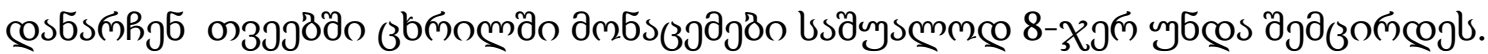

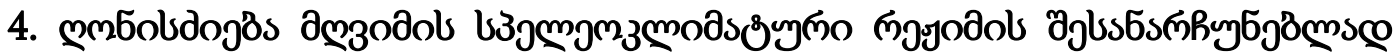

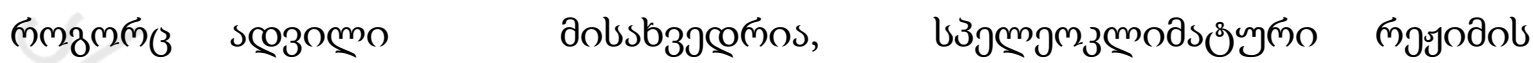

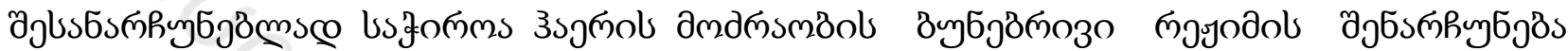

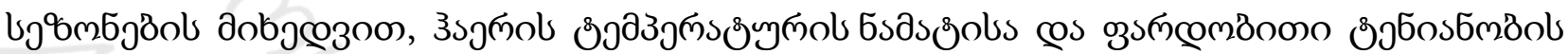

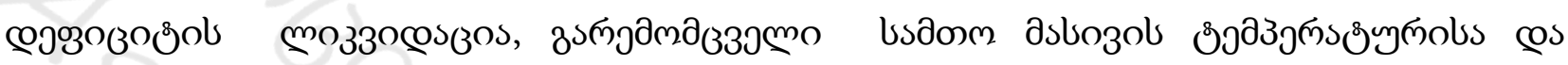

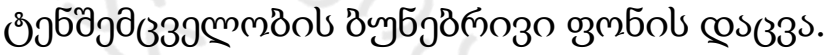

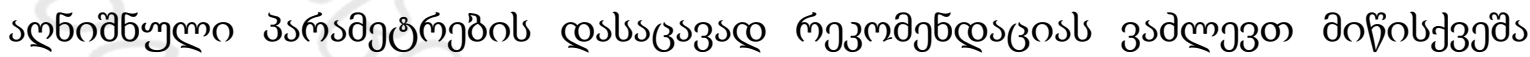

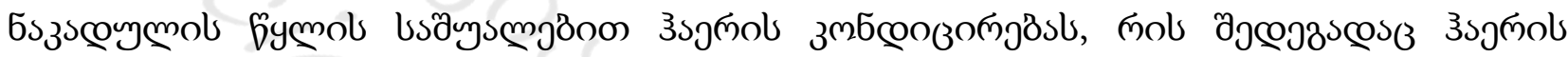

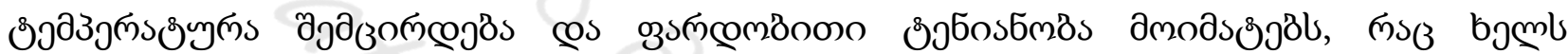

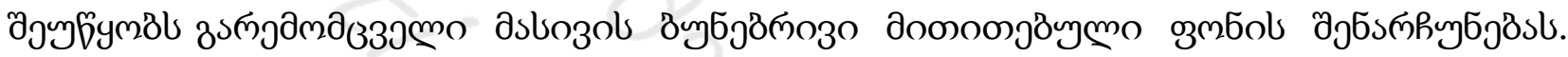

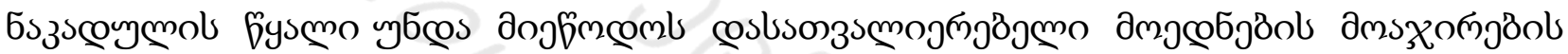

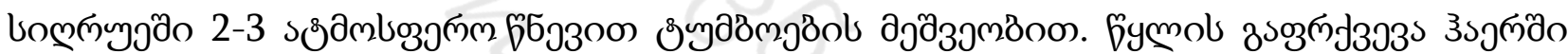

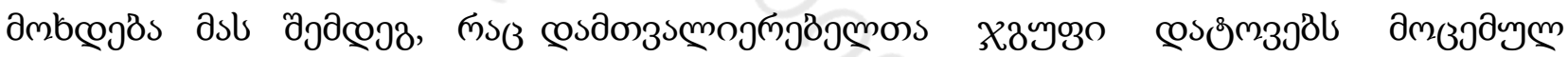

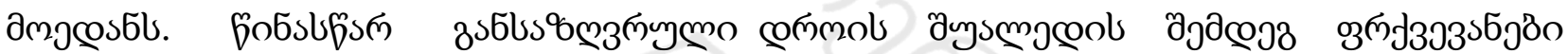

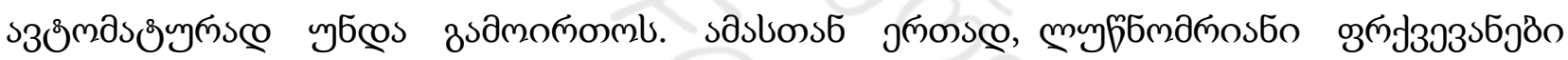

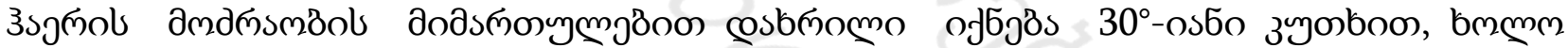

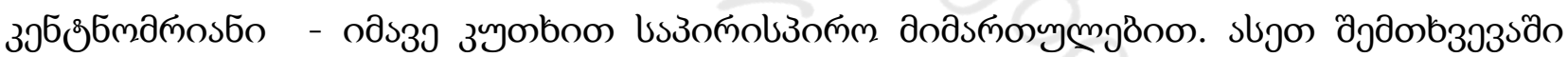

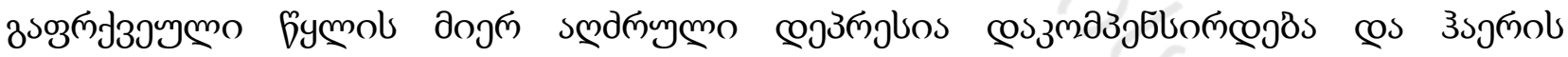

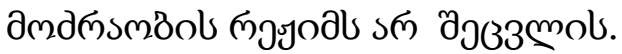

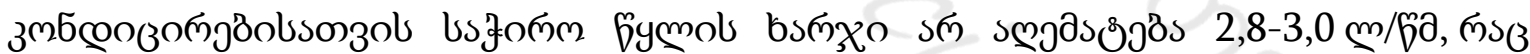

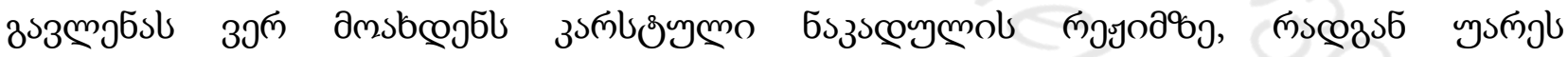

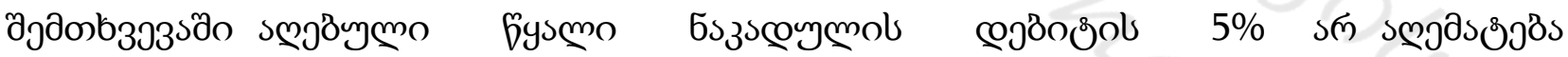

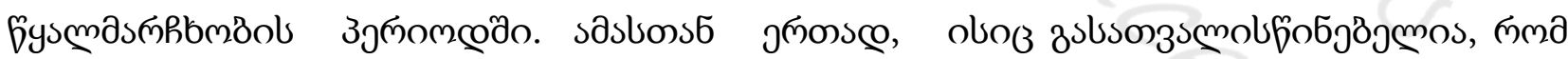

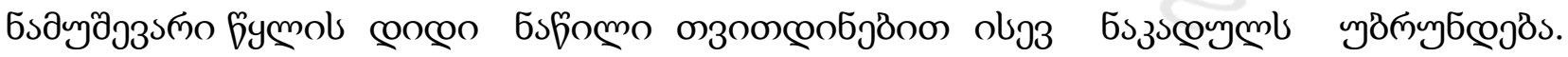

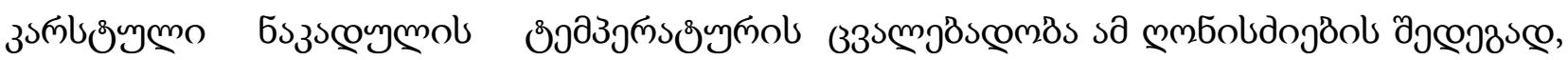

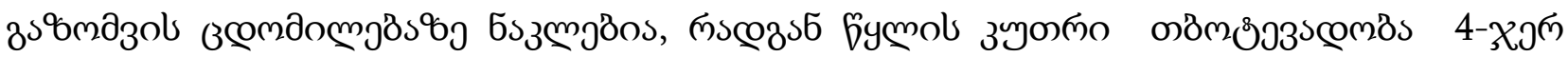

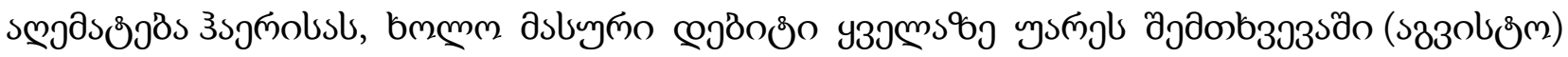

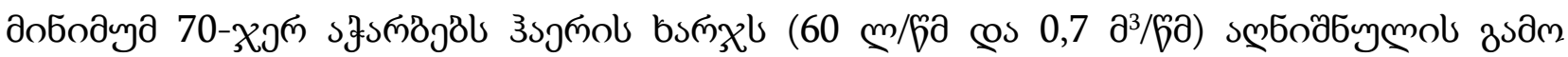

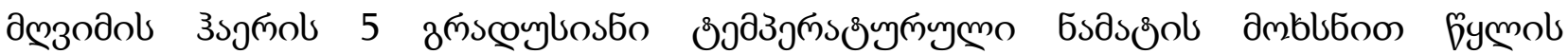

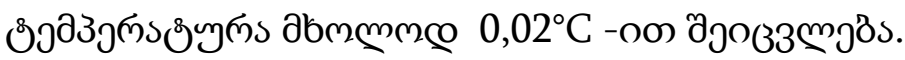

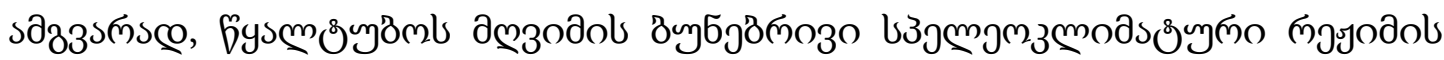

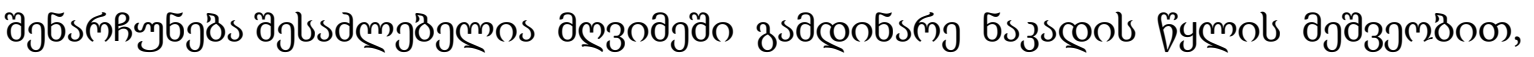




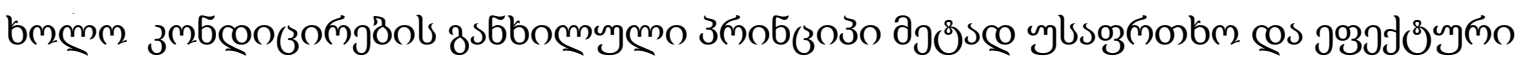
ofбวठ̊s.

\title{
NECESSITY OF PRESERVATION OF THE NATURAL CLIMATE OF TSKHALTUBO (KUMISTAVI) CAVE DURING ITS OPERATION
}

\author{
Lanchava $0 .{ }^{*}$ Tsikarishvili $K .{ }^{* *}$ \\ ${ }^{*}$ Grigol Tsulukidze Mining Institute \\ ${ }^{* *}$ Vakhushti Bagrationi Institute of Geography \\ Summary \\ To preserve the natural climate regime in the Tskhaltubo Cave Systems it is necessary to \\ carry out the permanent seasonal meteorological observations on the climatic parameters in the \\ underground area. Which will ensure the optimum operation of the cave system. By means \\ of mentioned conditions will be to the conservation and this facility. For preservation of the \\ natural regime of air circulation and for preservation of the optimum climate parameters, we \\ consider it is necessary to introduce the following restrictions: during the cold period, the \\ number of visitors should not exceed 7,000 person/season, and. in summer and spring - 2000- \\ 2700 person relatively. It is necessary to establish a special research laboratory. During the \\ operation of the cave, the following activities should be carried out systematically: \\ monitoring the inside environment microclimate: obtaining data on ionization and \\ radioactivity of the air. on gas and bacteriological compositions of the air. on changes in the \\ levels of underground waters according to diurnal and seasonal cycles and the attention should \\ be paid to the prevention of pollution.
}

\section{НЕОБХОДИМОСТЬ СОХРАНЕНИЯ ЕСТЕСТВЕННОГО КЛИМАТА ЦХАЛТУБСКОЙ (КУМИСТАВСКОЙ) ПЕЩЕРЫ ПРИ ЕЕ ЭКСПЛУАТАЦИИ}

\author{
Ланчава $O^{*}$ Цикаришвили $K .{ }^{* *}$ \\ *Горный Институт им. Г Цулукидзе \\ **Институт географии им. Вахушти Багратиони
}

Резюме

\begin{abstract}
Для сохранения естественного климатического режима Цхалтубской карстовой пещеры необходимо постоянные сезонные наблюдения за изменением
\end{abstract}


климатических параметров подземного пространства. Отмеченным будут выявлены условия, обеспечивающие сохранение и оптимальное функционирование этого объекта; для сохранения природного режима циркуляции воздуха и его оптимальных климатических параМетров необходимо примененик: следующих ограничений: в холодное время года, количество посетителей не должно превышать 7000 человек/сезон а весной и летом - 2000-2700 чел/сезон: необходимо создание специального научного стационара. За период эксплуатации пещеры систематически должны проводиться следующие мероприятия: - исследование состояния микроклимата пещеры и ее окрестностей; - научный анализ информации относительно радиоактивного фона и ионизации воздуха в пещерном комплексе; - исследование газового и бактериологического режима воздуха в подземном пространстве; - изучение сезонного изменения уровня подземной речки а также исследование состава поздемных вод.

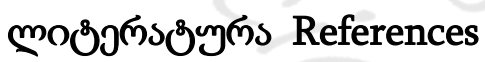

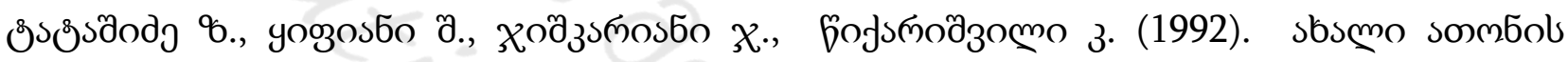

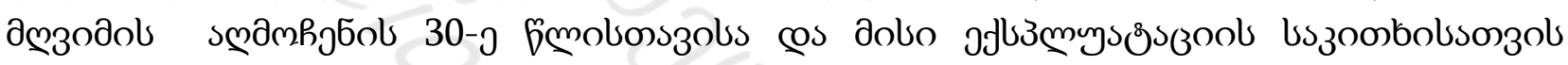

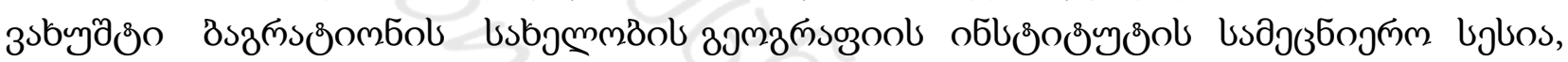
ов̈омпolo, 33. 12-14.

Jishkariani J., Tatashidze Z., Tsikarishvili K., Lanchava O. (2010). Main Results of Complex Research into the Tskaltubo Cave System. // Bulleten of the Georgian Academi of Sciences. vol. 4, no. 2, p. 92-95.

Ушаков К. З. И др. (1978). Рудничная аэрология. М., «Недра». 440 с. 